\title{
Metoklopramid trygt mot svangerskapskvalme
}

\author{
Bruk av metoklopramid under svangerskapet øker ikke risikoen for \\ misdannelser eller spontanabort.
}

Metoklopramid er mye brukt mot kvalme og oppkast i svangerskapet. Medikamentet har vært sett på som trygt å bruke, men sikker kunnskap om risiko for medfødte misdannelser og spontanabort har manglet.

I en dansk kohortundersøkelse er kvinner som brukte metoklopramid under svanger-

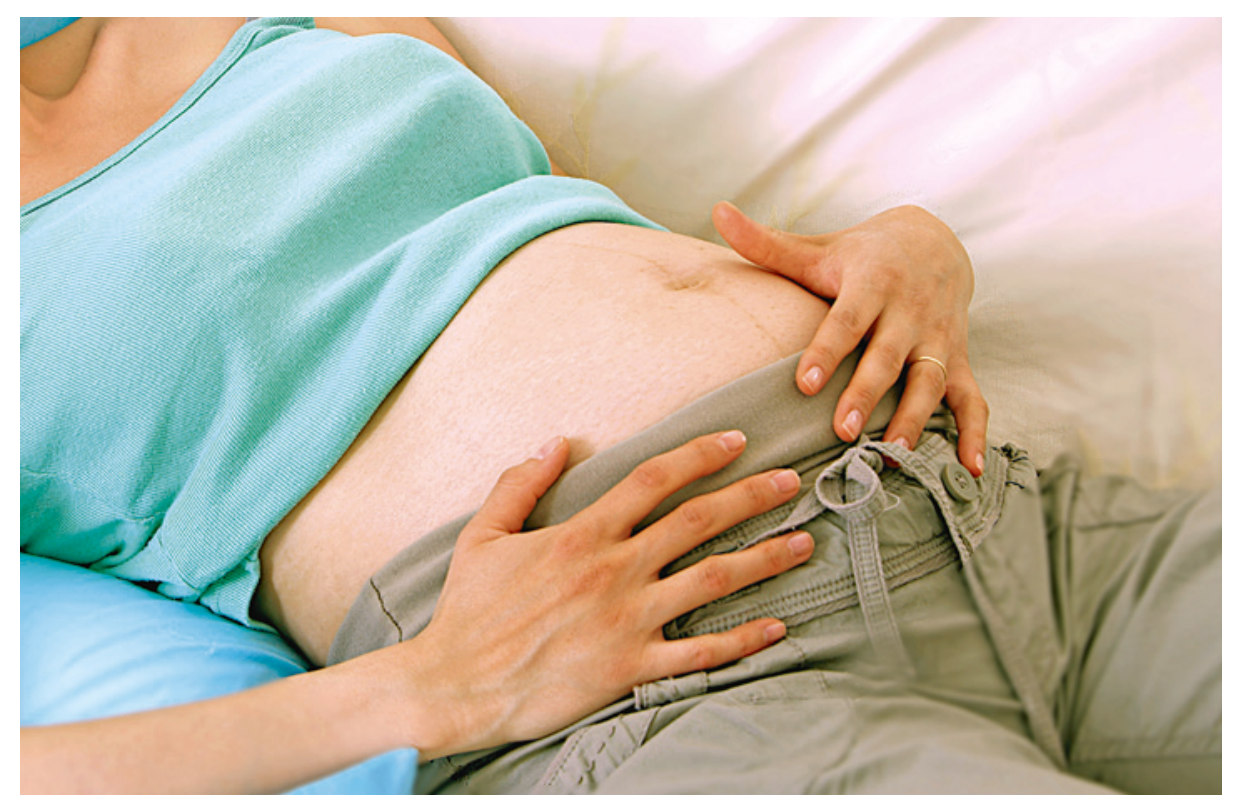

Foto: Thinkstock skapet sammenliknet med kvinner som ikke brukte medikamentet (1). Data fra mer enn 1,2 millioner graviditeter $\mathrm{i}$ perioden 1997-2011 ble hentet fra det danske fødselsregisteret, reseptregisteret og pasientregisteret. Av disse hadde over 45000 brukt metoklopramid i snitt 13 dager i løpet av

svangerskapet. Det var ingen økt risiko for spontanabort, dødfødsel eller misdannelser hos kvinnene som hadde brukt dette medikamentet.

- Gode epidemiologiske studier er den mest egnede måten til å vurdere om et legemiddel er fosterskadelig hos mennesker, sier Hedvig Nordeng, som er professor ved Farmasøytisk institutt, Universitetet i Oslo og forsker ved Divisjon for psykisk helse, Nasjonalt folkehelseinstitutt. - Studien er imponerende ikke bare på grunn av størrelsen og antall spesifikke misdannelser som ble studert, men også på grunn av den metodologiske grundigheten.

- Studien er også et godt eksempel på hvordan kobling mellom helseregistre kan bidra med etterspurt klinisk relevant informasjon. Funnene tyder på at metoklopramid kan være et alternativ ved svangerskapsrelatert kvalme når ikke-farmakologiske tiltak og antihistaminer ikke gir god nok lindring. Det er likevel relevant å minne om at europeiske legemiddelmyndigheter advarer mot bruk av metoklopramid over fem dager på grunn av faren for nevrologiske bivirkninger, sier Nordeng.

\section{Sigurd Høye \\ Tidsskriftet \\ Litteratur \\ 1. Pasternak B, Svanström H, Mølgaard-Nielsen D et al. Metoclopramide in pregnancy and risk of major congenital malformations and fetal death. JAMA 2013; 310: 1601-11.}

\section{Klinisk skåring av sår hals}

\author{
Bruk av klinisk skår ved sår hals er \\ like bra som streptokokkhurtigtest \\ for å avgjøre om behandling med \\ antibiotika bør iverksettes.
}

De fleste pasienter med sår hals som oppsøker lege i England, blir behandlet med antibiotika, til tross for at det kun er dokumentert en beskjeden symptomatisk effekt. Engelske og australske forskere har nå sammenliknet effekten av klinisk skår eller streptokokkhurtigtest med vent-og-se-resept på antibiotika (1).

Pasienter i alder tre år og oppover med akutt sår hals ble randomisert til én av tre grupper: klinisk skår (med skår 1-7), bruk av streptokokkhurtigtest basert på klinisk skår samt vent-og-se-resept (kontroll). 2-4 dager etter konsultasjonen var selvrapporterte symptomer lavere i klinisk skår-gruppen og i antigentestgruppen enn i kontrollgruppen. Symptomene forsvant raskere i klinisk skår-gruppen enn i kontrollguppen (hasardratio 1,30). Andelen som fikk forskrevet antibiotika i klinisk skår-gruppen og streptokokkhurtigtestgruppen var lavere enn i kontrollgruppen.

- Dette er en grundig studie, der forfatterne har utviklet et nytt skåringssystem som predikerer tilstedeværelse av streptokokker bedre enn de relativt velkjente Centor-kriteriene, sier Sigurd Høye, som er forsker ved Antibiotikasenteret for primærmedisin ved Avdeling for allmennmedisin, Universitetet i Oslo.

- Resultatene viser at dette skåringssystemet fungerer like godt som hurtigtest. I norsk allmennpraksis er imidlertid bruk av streptokokkhurtigtest svært utbredt, og det er verken mulig eller ønskelig å bytte ut denne med et skåringssystem.

- Studien viser likevel at testen ikke bør brukes til å styre antibiotikaforskrivning hos pasienter med lav symptomskår, da disse kan være friske bærere av streptokokker, eller hos pasienter med høy symptomskår siden testen ikke avslører gruppe C- og Gstreptokokker, avslutter Høye.

Trine B. Haugen

Tidsskriftet

Litteratur

1. Little P, Hobbs FDR, Moore M et al. Clinical score and rapid antigen detection test to guide antibiotic use for sore throats: randomised controlled trial of PRISM (primary care streptococcal management). BMJ 2013; 347: f5806. 